\title{
Regional Branding: Transfers Medium Dance into Visual Identity in Ponorogo Image Construction
}

\author{
Agus Budi Setyawan ${ }^{1}$, Nanik Sri Prihatini², Sri Rochana W. ${ }^{3}$, Didit \\ Widiatmoko Soewardikoen 4 \\ ${ }^{1}$ Faculty of Design and Creative Arts, Mercu Buana University, Jakarta, Indonesia. Email: \\ budi.setyawan@mercubuana.ac.id. ORCID id: oooo-ooo1-7829-5433 \\ ${ }^{2}$ Postgraduate Program, Institut Seni Indonesia (ISI), Surakarta, Indonesia. Email: \\ nanik@isi-ska.ac.id. ORCID id: oooo-0oo2-1272-002x \\ 3 Postgraduate Program, Institut Seni Indonesia (ISI), Surakarta, Indonesia. Email: \\ rochana@isi-ska.ac.id. ORCID id: oooo-0oo3-0256-2958 \\ ${ }^{4}$ Faculty of the Creative Industry, Telkom University, Bandung, Indonesia. Email: \\ diditwidiatmoko@telkomuniversity.ac.id.ORCID id: oooo-0oo2-1272-7026
}

\begin{abstract}
This article discusses how the people of Ponorogo, East Java, Indonesia, designed a visual identity as a representation of Reyog dance to build up a regional image through a series of branding communication activities. This study uses a qualitative paradigm with a case study approach. The data was collected through in-depth interviews, participatory observation, and document investigation. All data collected were analyzed using an interactive model. The results showed that the five characters of the Reyog dancer were represented as a visual identity for Ponorogo branding through the process of media transferring using photography, illustration, and sculpture techniques. Reyog's visual identity with motion characteristics is implemented in each channel of branding communication media through primary, secondary, and tertiary communication approaches. Other local governments can use these research results as a model to build up a regional image through dance media.
\end{abstract}

Keywords: Regional Branding, Visual Identity, Reyog, Ponorogo, Indonesia.

\section{Introduction}

Based on Law Number 22 the Year 1999 (revised into Law Number 32 the Year 2004) concerning Regional Autonomy, every region in Indonesia is given the authority to regulate itself, be active, and creatively earn regional revenue. Various programs are made to make a region unique and attractive to tourists and investors, one of the regional branding concepts.

Until 2019 there were 74 regencies/cities out of 514 regencies/cities in Indonesia implemented the branding concept to improve the regional economy. The use of regional brands is based on local characteristics and identities by utilizing regional assets in cultural arts, natural environment, agricultural products, processing, culinary, services, industry, education, architecture, and facilities.

(c) Authors, 2021. This Open Access article is published under a Creative Commons Attribution Non-Commercial 4.0 International License (http://creativecommons.org/licenses/by-nc/4.o/), which permits non-commercial re-use, distribution, and reproduction in any medium, provided the original work is properly cited. For citation use the DOI. For commercial re-use, please contact editor@rupkatha.com. 
Ponorogo Regency, East Java, Indonesia, is one of the regions that apply branding by utilizing its cultural arts assets. According to data from the Ponorogo Regency Bappeda (2016, p. 44-45), there are 31 types of traditional arts that have developed in the Ponorogo community, among which the most popular are: Reyog, Karawitan, Hadroh, Gajah-Gajahan, Orkes Melayu, Qosidah, Campursari, Jaranan, Ketoprak, and Odrot. From a total of 950 art groups, the Reyog art group is the largest. The number of Reyog art groups reaches 259 groups and spread across almost all Ponorogo region villages.

As the most famous art in Ponorogo, Reyog dance is preserved and used to build up a regional image through branding activities. Regional branding activities are not limited to created slogans or logos. However, they are the soul that animate all regional activities, be it the soul of its citizens, the bureaucracy character, the availability of supporting infrastructure, and the arrangement of regional visual elements as a complement (Karim and Pontoh, 2012, p. 2).

Reyog's visual elements presented in the Ponorogo branding communication media look flexible and humanist so that it plays a role in attracting public attention. Hospers (2009, p. 232) stated that the effective use of pictorial representations distributed through the media could be a powerful tool for marketing an area. Turok (2009, p. 17) states that the principles underlying the selection of images to describe an area in marketing materials contribute to developing attractive marketing messages, especially in terms of creating attractiveness and distinctiveness.

Creating a representative visual identity design cannot be separated from the awareness of the importance of visuals to convey information (Tabrani 2009, p. 8). Everyone in understanding visuals will follow the context discussed, as suggested by Rose (2001) and Ida (2014, p. 128). According to Knapp (2002, p. 19) and (Sihombing 2010, p. 1), branding communication messages with image elements presented graphically are more effective in optimizing the awakening of audience perceptions.

Perception is related to image formation and how messages are received, including various associations, memories, hopes, and other feelings that drive people's behaviour (Anholt, 2007, p. 5). Image refers to the audience perspective in translating signals sent through a communication process consisting of message senders, messages, media channels, and message recipients (Kepferer, 2008, p. 174).

Several studies have been published on image construction through the use of traditional arts with similar problems. Research conducted by Yurisma et al. (2018, p. 13) shows that the image of Ponorogo as the City of Reyog is based on physical and non-physical elements. The physical elements are in the form of a region dividing gate, traffic lane, and the town square-non-physical elements in the form of slogans, visual symbols, and activities. The presence of physical artefacts represented by Reyog attracts the attention of the public. Research by Handoko et al. (2020, p. 918) shows that the Ponorogo image is formed by holding regular monthly and annual events. Monthly show events include the Reyog Telaga Ngebel, Reyog Purnama, and the Gebyar Reyog rural celebrations. National show events include the Student Reyog Festival and the National Reyog Festival. The activities carried out have made Ponorogo a nationally recognized cultural city.

This research focuses on how the people of Ponorogo design the visual identity of the Reyog dance and how its implementation in Ponorogo branding communication activities. These research results are significant because other local governments can use them as inspiration to build up a regional image by using the dance art assets.

The discussion in this study uses a media transfer theory and an image communication theory approach. The transfer of means is through moving one type of medium to another to 
express, achieve, or exhibit ideas or feelings, as stated by Damono (2016, p. 13). Image communication theory is used as presented by Kavaratzis (2004, p.64); image communication is done through three types of communication: primary, secondary, and tertiary communications. Primary communication emphasizes the potential influence and actions taken by a region, including landscape strategy, infrastructure projects, organizational and administrative structures, and behaviour. Secondary communication is related to intentional and planned venue marketing activities using promotional and advertising components. Tertiary communication refers to the worth of mouth communication enhanced by the media and competitor communication activities.

\section{Research Methods}

This study uses a qualitative paradigm that is analytic descriptive by revealing events or facts, variables, and circumstances that occur in Reyog as a visual identity used by the Ponorogo community to build up a regional image through a series of appeal activities. Qualitative research is an independent, multidisciplinary field of inquiry linked to cultural studies and has an interpretive character through extensive and profound data deepening (Denzin \& Lincoln 2005, p. 2).

Researchers collected data through in-depth interviews with many individuals related to Ponorogo branding activities. For data deepening, participatory observation and document tracking techniques are used. The research data was tested for accuracy and correctness using triangulation by comparing different data sources to explore the same data. If there was a synchronizing, then the data is considered valid. The data collected were then grouped into invariant cases and coded for analysis using an interaction model. Miles and Huberman (1994, p.1011) State that interaction analysis consists of three main streams: data reduction, data presentation, and conclusion drawing.

\section{Result}

For the people of Ponorogo, Reyog is not just a performing art; Reyog is an identity that will be maintained at all costs because Ponorogo is synonymous with Reyog, an art that has become inseparable part of the life of its people. Reyog dance is used as a regional asset. Its existence is used to build up the Ponorogo image through a series of planned, integrated, and sustainable branding communication activities.

The people of Ponorogo use Reyog dance as a visual identity through a process of transferring media art with the approach of photography, illustration, and sculpture techniques. Reyog's visual identity with movement characteristics is made by considering the dancer's posture, expression, artistic, and compositional aspects.

Reyog's visual identity resulting from transferring means is implemented in various Ponorogo branding communication media through a series of image communication activities consisting of primary, secondary, and tertiary communications. These activities have contributed to Ponorogo fame and the increase of the tourists visiting Ponorogo each year, which has led to the improvement of the community's economy and regional income. 


\section{Discussion}

\section{Ponorogo's Reyog Dance Art}

Reyog is often performed at various celebratory events and organized by governmental institutions, the private sector, community groups, and individuals as a folk entertainment art. For example, the Republic of Indonesia's independence day, the celebration of national holidays, political party campaigns, regular regency government programs, village cleansing rituals, weddings, circumcisions, etc.

Reyog performances require an open area with a high ceiling because the Barongan mask's height can reach up to 4 meters. Reyog performance usually takes place during the day, between 2 $\mathrm{pm}$ and $6 \mathrm{pm}$. There are not many Reyog performances at night, as it will require a more lighting system. The Reyog performance duration is at least 30 minutes, which occurs in the national Reyog festival, and the longest is up to 4 hours, mainly if the performances include a procession (Simatupang 2019, p. 148-149).

There are various forms in Reyog art developed in the community, from Reyog Obyok; Reyog Panggung (stage); Reyog Santri; Reyog Pelajar (student); and now appears Reyog Perempuan (woman). Although they have many variations with their respective characteristics, they have similarities in the performance component, including the performance types of equipment, the gamelan instruments, the various dances, clothing, and make-up use. The Reyog performances include Barongan; Mask Kelana Sewandana; Samandhiman's whip, Bujangganong mask; and Eblek (horse-shaped plait). In Reyog performances, Barongan or Dadak Merak acts as the central figure and completes the show. Its presence is mandatory because it serves to initiate and close the performance. See figure 1.

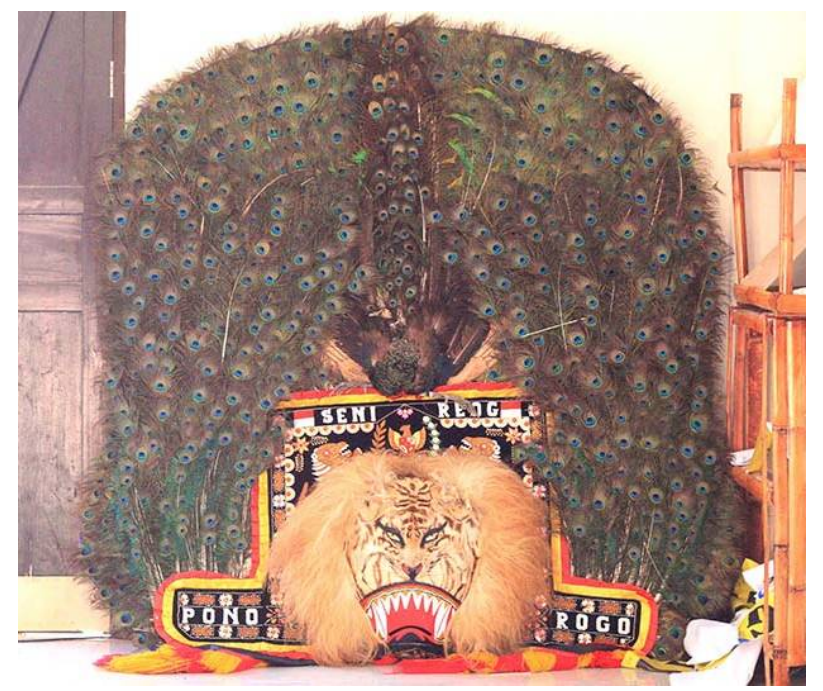

Figure 1: Barongan Reyog Ponorogo's. Source: author, 2019

Barongan consists of two sets, namely Dadak Merak and Caplokan. Dadak Merak is the upper part of Barongan, which is made of peacock feathers with about 1500-200o feathers arranged in such a way on a Dadak Merak frame made of bamboo rattan a raft with a height of around 3-5 meters. Caplokan is Reyog's head in the form of a mask framework with a shape resembling a tiger's head, made of randu tree wood wrapped in real tiger leather. Barongan weighs more than 5o-kilo grams, played by biting the wooden handle located inside the Barongan mask (Government of Ponorogo Level II District, 1994, p. 105). 
The gamelan instruments that accompany the Reyog stage consist of trumpets, drums, ketipung, kempul, kethuk and kenong, and angklung - the trumpet functions as a melody and signal before the gamelan played. Kendang functions as a signal at the beginning of the gending, accompanying dance movements, controlling the rhythm, and adjusting the tempo of the gending. Ketipung serves as a lively musical addition. Kempul functions as bass. Kethuk and Kenong, functioning as rhythmic, are struck alternately with a rhythm in tune with their tempo. Angklung functions as a rhythm and accompaniment between kethuk and kenong (Government of Ponorogo Regency 2013, pp. 15-18).

The various dances in the Reyog art performance consist of: Warok Dance, the dance movements seem heavy and broken, playing a role in creating an atmosphere full of dignity, charisma, and solemnity; Jathil dance is often referred to as the Jaranan dance, depicting the dexterity of horse riders who are training in war; Pujangganong dance, the dance movements are agile, attractive, funny and always create a sensation that symbolizes the life that is not always straight and smooth; Klana Sewandana dance depicts fair and wise leadership with scientific integrity that has reached the pinnacle of perfection and personality integrity which oriented towards welfare and justice; and the Dadak Merak Dance, as a dance that must always be on the Reyog stage because its presence is the same as the existence of Reyog art itself (Kurnianto 2017, p. 37-56).

The clothes worn by the Reyog dancers' character have a full variation of characteristic accessories, as stated by Soemarto (2014, p. 41-55). Kelana Sewandana figures use clothing in the form of mask, mirror and stretches, cinde pants, uncal, epek timang, boro-boro, jarit parang, sampur, cakep, keris, shoulder kelat, probo, samandiman whip, binggel, and stagen. Bujangganong characters wear clothing in bujangganong mask, black trousers, binggel, embong gombyok, epek timang, stagen, cakep, sampur, and red vest. Jathil figures wear clothing in the form of eblek, gulon ter, srempang, iket, white long-sleeved shirts, blackened pants, kace, boro-boro, samir, jarit parang, sampur, and epek timang. Barongan figures use clothing in barong mask, stagen, embong gombyok, black trousers, timang epek, cakep, and a vest shirt. Warok figure clothing is in gembrong baggy black pants, jarit cloth with a black background, stagen, drawstring, timang epek, wakthung shirt, pocket watch, blangkon/udeng, and keris gabelan.

Make-up is only used by dancers who do not wear masks, namely Jathil and Warok dancers. Jathil dancers use subtle male make-up (approaching valour), and Warok dancers use dashing and spooky make-up (Government of Ponorogo Regency 2013, p. 24).

Reyog's art performance plot consists of opening dances, the core dance, and the closing dance. The opening dance starts with the Warok dance played by male dancers, followed by female dancer's Jathil dance. After the opening dance finished, it continued with the core dance, which contains the scene according to the Reyog dance program. In general, the scenes shown are about love stories or warrior stories. It ends with a closing dance featuring the Dadak Merak, Klana Sewandana, and Bujangganong dances, with scenes of Klana Sewandana defeats Singa Barong (Dadak Merak).

In every appearance, Reyog provides entertainment that is fresh and exciting. The dance movements are agile and full of heroism, beautiful clothing full of authority, and dynamic instrument accompaniment that can create admiration and joy. Reyog's fame has made Ponorogo an area that is reckoned with in the map of traditional arts in Indonesia, so it is not surprising that many people are interested in this art. Reyog is widely used for various purposes, ranging from academic activities, preaching media, entertainment performances, tourism-based performances, 
local and national festivals, publications, political party campaigns, to commercial activities (Kurnianto 2017, p. 1).

\section{The Transformation of the Reyog Dance Form into a Visual Identity}

Reyog has a beautiful visual appearance and is to be proud of. Reyog's visual appeal can see in the form, appearance, and variety of dance movements. In Reyog dance, there are five characterizations, each of which uses clothing with different shapes and appearances. Likewise, with the movements, each character has movement characteristics that look expressive and have character.

Special consideration is needed to produce a representative Reyog visual identity design to meet Ponorogo's visual branding communication needs. According to Wondo (Personal communication. 2019, September 10), the presentation of Reyog's visual identity for Ponorogo branding must look impressive and have character. According to Sodiq (Personal communication. 2019, September 12), Reyog's impressive visual identity is related to the willingness to embody an expression in dance seriously with a strong soul.

To create a strong impression of Reyog's visual identity, it is necessary to understand the lines and symbols of motion reflected in Reyog's dancers' posture. According to Devi (1972, p. 30), there are four ideal postures of the body for sculpture and other arts and crafts, i.e., Samabhanga, Abhanga, Atibhanga, and Tribhanga. Samabhanga is a movement with the same balance arc. The Abhanga is a slight bowing motion with one hip gracefully raised, body weight supported on one leg. Atibhanga is a large bend with the torso tilted diagonally and the knees bent (plie). The Tribhanga is a triple bend with one hip raised, the torso arched to the opposite side, and the head tilted at an angle. Understanding the Reyog dancer's body posture plays a role in creating a Reyog dancer's character's visual identity with their movement characteristics.

Besides that, according to Cahyo (Personal communication. 2019, September 12), Reyog's impressive visual identity can be seen from the expression of the Reyog dancer's character created because of the emotional attachment between one display and another in a Reyog performance arena. Agree with that, Sugeng (Personal communication. 2019, September 12) added that Reyog's impressive visual identity is also created by fulfilling artistic and composition elements.

According to Najih (Personal communication. 2019, April 27), to create a Reyog visual identity that is strong and characterized by motion, artistic skills in graphic design and photography are needed. Graphic design technical skills are needed because images tell a story, have strong appeal, and increase the likelihood of a noticeable message. Expertise in photography is needed to relate to how the shooting angle and the ability to capture the scene's momentum in a Reyog show with excellent lighting quality, focus, and ideal composition.

Furthermore, according to Sugeng (Personal communication. 2019, September 12), the short scene momentum becomes a lack of getting all Reyog characters' artistic quality in one shot photo. A solution can use the collage technique by combining several photos of Reyog's artistic characters into one complete visual composition. Wandi (Personal communication. 2019, September 10) stated that for the needs of Ponorogo branding communication, five Reyog characters could be read separately, in pairs, and ultimately, according to their needs.

Understanding each character's characteristics in Reyog is necessary to select the show's most characteristic fragment parts. Najih (Personal communication. 2019, April 27) provided an overview regarding the criteria used to determine the Reyog character is to become the visual 
identity of the Ponorogo branding. The character of the Dadak Merak (tiger head) mask used must be handsome, dignified, fierce, and reads "Seni Reyog Ponorogo." The Warok dancer's character must show dramatic dance moves, have an aggressive appearance, and use the right clothing attributes. The Jathil dancer's character wears white clothes with a combination of black, yellow, and red. The Bujang Ganong dancer's character must show agile and attractive dance moves with hair movements. The Klono Sewandono dancer's character must show authoritative dance movements, the direction of the face, the costumes used, and the dancer's proportional posture.

In line with that, Wondo (Personal communication. 2019, September 10) said that the most characteristic visualization of the Dadak Merak was seen in the obyok movement (the wagging movement of the Dadak Merak), the Kupu tarung (the movement in pairs facing each other and wagging the Dadak Merak), and the sampak (resembling the movements of a tiger). The visualization of Klono Sewandono must show dignity (like a king); the visualization of Bujang Ganong shows dance moves that look lively; Jathil shows a dance move on an eblek, looks excited with a small smile; and for Warok, the appearance must look fierce.

The transformation of the Reyog dance media by the people of Ponorogo into a visual identity for branding can be seen from the physical artefacts that characterize the Ponorogo area. By observing how these physical artefacts appear, it becomes clear how the media transfer technique is used. The description of the transfer media's techniques and results can be seen in the following table 1.

Table 1: The Matrix of the Reyog medium being transformed into a visual identity for Ponorogo branding

\begin{tabular}{|c|c|c|c|}
\hline \multirow{2}{*}{$\begin{array}{l}\text { Reyog's } \\
\text { Character }\end{array}$} & \multicolumn{3}{|c|}{ Result Media Transfer } \\
\hline & $\begin{array}{l}\text { Photography } \\
\text { Approaching }\end{array}$ & $\begin{array}{l}\text { Illustration } \\
\text { Approaching }\end{array}$ & $\begin{array}{c}\text { Sculpture } \\
\text { Approaching }\end{array}$ \\
\hline $\begin{array}{l}\text { Klono } \\
\text { Soewandono }\end{array}$ & : & (7) & \\
\hline Bujang Ganong & GREBEG & $K_{R}=r$ & \\
\hline
\end{tabular}

Jathil 


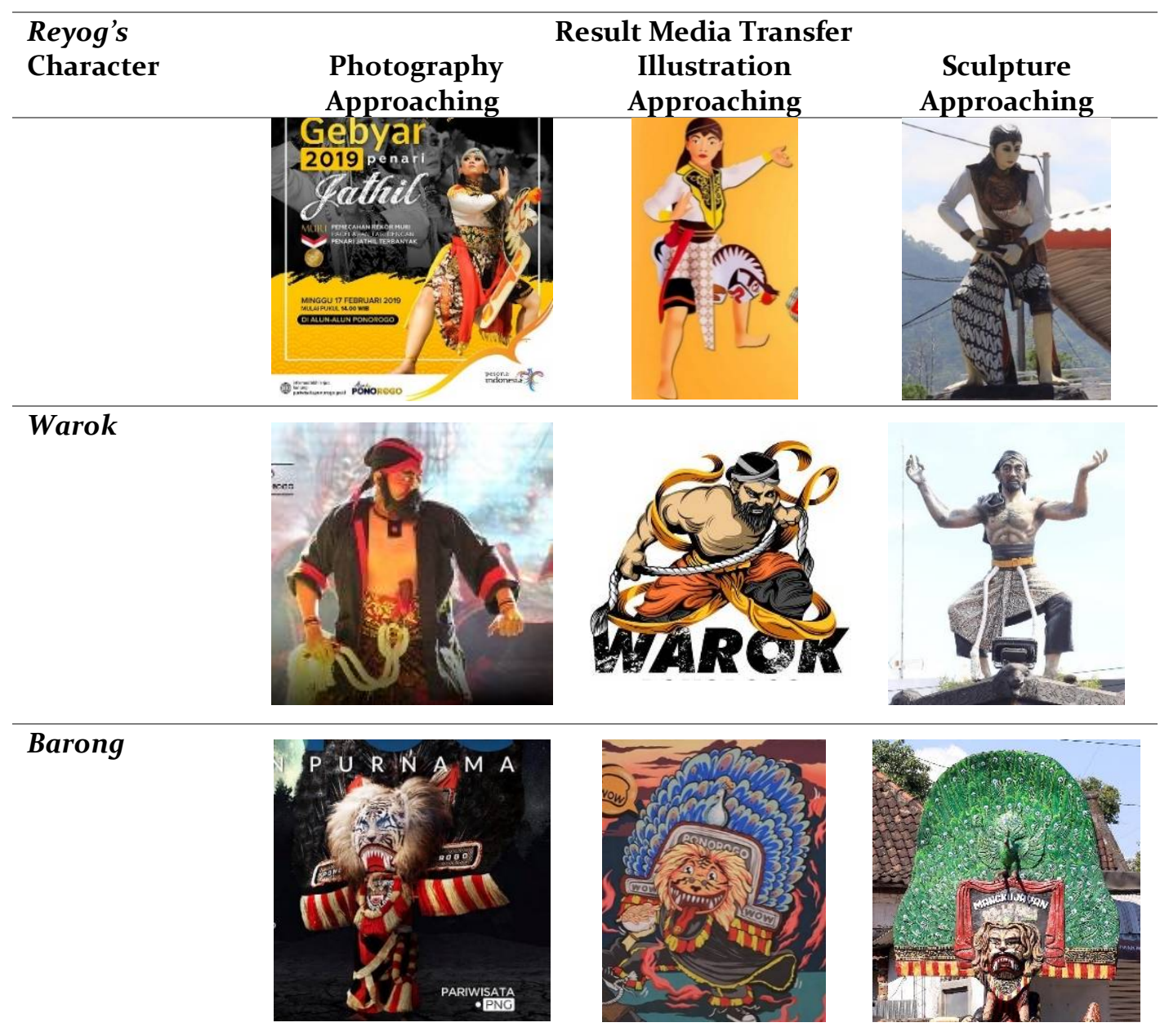

Based on data from Reyog's physical artefacts made by the people of Ponorogo, it is known that the visual identity that represents the character of Reyog's dancers was created through a media transfer using the approach of photography, illustration, and sculpture techniques. The approach through the photography technique is made by taking photos directly when the Reyog dance is performed. It takes photography technique skills and captures momentum to produce Reyog dancers' images with character. The illustration approach was made through digital and manual processing. The digital processing is carried out using vector-based computer graphics software. The manual illustration is made with a mural approach. The sculpture technique approach is used to produce a Reyog dancer's character in the form of a 3-dimensional.

The characteristics of the movement in Reyog's visual identity, as the result of the media transfer of the Ponorogo community, can be seen through the appearance of the Reyog dancer's characteristic posture. The postures displayed characterizing the postures of the Samabhanga and Atibhanga. See figure 2. 


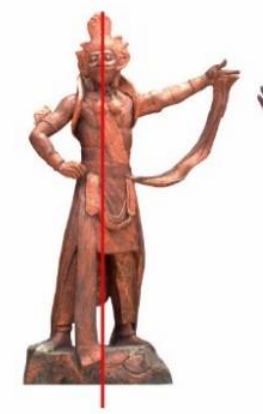

Samabhanga

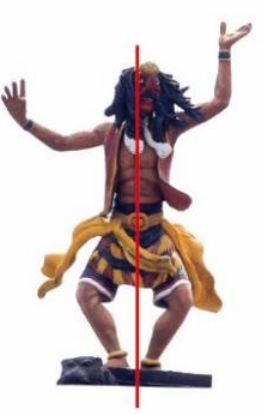

Samabhanga

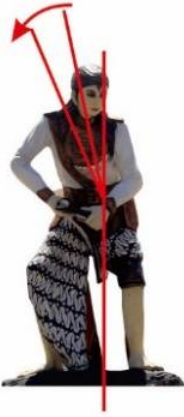

Atibhanga

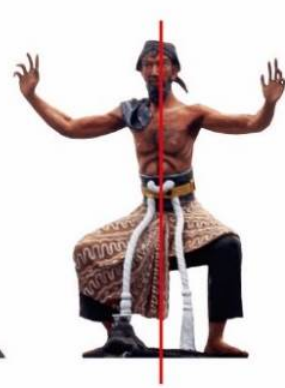

Samabhanga

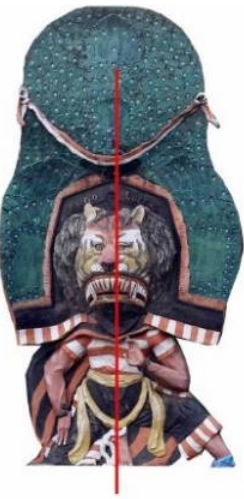

Samabhanga

Figure 2: The posture of Reyog's visual identity character as a result of the media transfer. Source: author, 2019

\section{Implementation of Reyog Visual Identity through Branding Activities}

Ponorogo Regency image is formed from the audience's perception, constructed through three types of communication: primary, secondary, and tertiary communication.

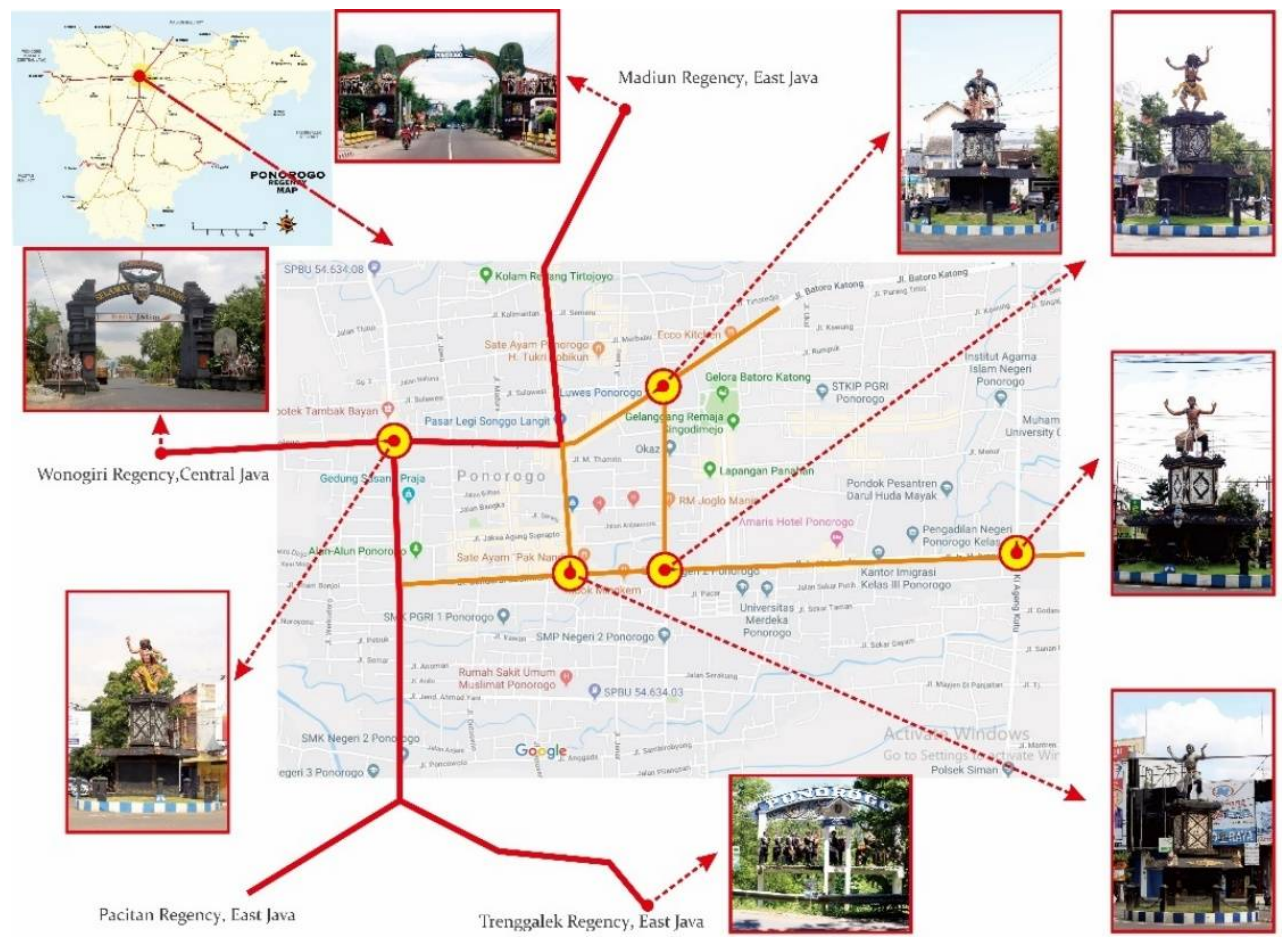

Figure 3: Landmark placement of the Reyog's character. Source: author, 2019

Primary (internal) communication activities are carried out by constructing landmarks in the form of gates decorated with Reyog statues and reliefs on the border with other regency (Wonogiri, Madiun, and Trenggalek), village entrance gates and a number of main road crossing points, infrastructure development in the form of a covered or open stages to supporting the Reyog performances, Reyog village development, naming city parks and government asset buildings using the names of characters in Reyog, the application of rules for male employees in the Ponorogo government environment to wear penadon clothes (Warok clothes) during the Grebeg Suro 
celebration (in the month of Muharram in the Islamic calendar) and on the $17^{\text {th }}$ of every month, routine Reyog performances at local and national levels, such as Reyog Purnama which is routinely held every full moon night, Reyog Telaga Ngebel, Reyog Serempak celebration on the $11^{\text {th }}$ of each month, Reyog Mini festival and National Reyog festival which are routinely held every year.

Secondary (external) communication activities are carried out through advertising and promotion by implementing Reyog's visual identity in various print-based and electronic visual communication media delivered offline and online. The printed media used include billboards, street banners, brochures, and umbul-umbul (Flag). The online media used include video profiles, web marketing, and social media. Youtube, Facebook, Twitter, Instagram, and Pinterest channels communicate and convey information related to Ponorogo branding activities to a broad and nonpaid audience.

Table 2: The use of social media in Ponorogo branding communication activities

\begin{tabular}{ll}
\hline Social Media & Link Address \\
\hline Youtube & Ponorogo Tourism \\
\hline Facebook & https://www.facebook.com/ponorogotourism \\
\hline Twitter & https://twitter.com/TourismPonorogo \\
\hline Instagram & https://www.instagram.com/ponorogotourism/ \\
\hline Pinterest & https://id.pinterest.com/ponorogotourism/_saved/ \\
\hline
\end{tabular}

The tertiary communication aspect is advertising communication carried out by the public by word of mouth as a form of satisfaction with what they experienced when visiting Ponorogo. Visitors who are satisfied with Ponorogo will recommend Ponorogo as a unique and exciting place to visit.

Through a series of branding communication activities carried out, Ponorogo is increasingly known. Based on tourist visit data from the Ponorogo Culture and Tourism Office, the number of tourist visits in Ponorogo has increased significantly.

Table 3: Ponorogo tourist visit data. Source: Ponorogo Culture and Tourism Office, 2019

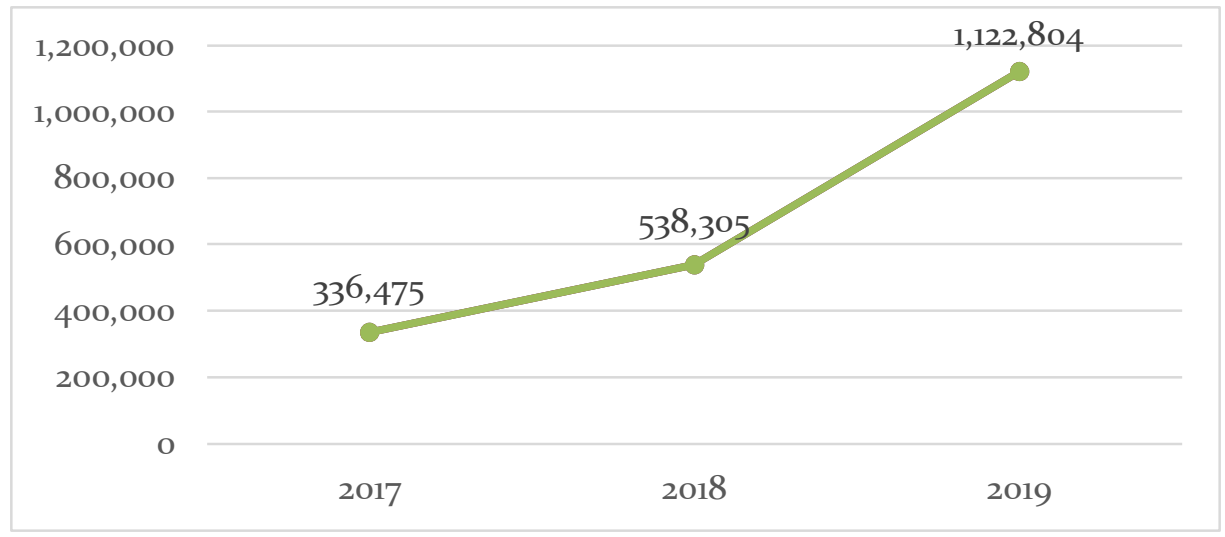

The increase in tourist visits that occurred also contributed to an increase in the regional economy. The value of the Gross Regional Domestic Product (PDRB) of Ponorogo Regency based on constant prices in 2017 of IDR 12.93 trillion, in 2018 increased to IDR 13.62 trillion, and in 2019 it 
increased significantly to IDR 20.50 trillion (Central Statistics Agency of Ponorogo Regency, 2020. p. 18).

\section{Conclusion}

Reyog dance is a cultural identity of the people of Ponorogo; Its existence is used as a regional asset and is used to build the image of Ponorogo through a series of consistent, integrated, and sustainable branding activities.

The Reyog dance with attractive and dynamic dance movements is transformed into a static visual identity with motion characteristics. The media transformation of the Reyog's visual identity, carried out by the Ponorogo community, uses photography, illustration, and sculpture techniques. Reyog's visual identity, characterized by movement, is made by considering aspects of the dancer's body posture, expression, artistic, and representative composition. The body pose of the Reyog dancer seen in the visual identity of Reyog as a result of the media transfer characterizes the body postures of the Samabhanga and Atibhanga.

The intense emotional ties between Reyog's characters in one arena of the show create expressions that become benchmarks in the designing of Reyog's visual identity. Artistic layouts in graphic design, photography, and sculpture are needed to present Reyog's representative visual identity. Five Reyog dancers' characters can be presented in a single, paired, and complete visual composition tailored to the branding communication that needs to be conveyed. Reyog's visual identity resulting from a media transfer that is representative and characterized by movement has been implemented in every Ponorogo branding communication channel, including static media through primary, secondary, and tertiary communication types. The local government's branding communication activities and the Ponorogo branding community have significantly contributed to improving the community's economy and have contributed to the regional incomes.

\section{Funding Disclosure/Acknowledgement}

This research would not have been successful without the help of various parties, including the Faculty of Design and Creative Arts, Mercu Buana University, with the research permission granted; Education Fund Management Institution (LPDP), and the Ministry of Finance of the Republic of Indonesia, for the provision of funds.

\section{References}

Anholt, S. (2007). Competitive Identity, The New Brand Management for Nations, Cities, and Regions. New York: Palgrave Macmillan.

Creswell, J.W. (2015). Penelitian Kualitatif dan Desain Riset, Memilih di antara Lima Pendekatan. Edisi Ketiga. Yogyakarta: Pustaka Pelajar.

Damono, S. D. (2016). Alih Wahana. Jakarta: Editum.

Denzin, N. K., \& Yvonna S. L. (2005). Hand Book of Qualitative Research, zrd edition. USA: Sage Publication. Devi, R. (1972). Dance Dialects of India. Delhi: Jainendra Prakash Jain At Shri Jainendra Press, 30.

Handoko, L. A., Hermansyah, P., Kharisma, N., Septiyana,T. N., Saputri, T. P., Dewi, D. S. K., \& Manggala, H. (2019). Kota Reyog Sebagai City Branding Kabupaten Ponorogo (Analisa Akun Instagram 
@Pariwisatapng). Prosiding Simposium Nasional Tantangan Penyelenggaran Pemerintahan Di Era Revolusi Industri 4.0, p. 918-930.

Hospers, G.-J. (2009). Lynch, Urry and city marketing: Taking advantage of the city as a built and graphic image. Place Branding and Public Diplomacy, 5(3), 226-233. https://doi.org/10.1057/pb.2009.10

Ida, R. (2014). Metode Penelitian Studi Media dan Kajian Budaya. Jakarta: Prenada Media Group.

Kapferer, J. N. (2008). The New Strategic Brand Management: creating and sustaining brand equity long term. 4th ed. London and Philadelphia: Kogan Page.

Karim, M. Y., \& Pontoh, N. K. (2012). Image Kota Cirebon Sebagai Pembentuk Brand Kota Cirebon. Working Paper Urban Planning and Design Research Group, School of Architecture, Planning, and Policy Development, Institut Teknologi Bandung, 02 (12), 1-12.

Kavaratzis, Michails. (2004) From City Marketing to City Branding: Towards a Theoretical Framework for Developing City Brands. Place Branding, 1 (1), 58-73.

Knapp, D.E. (2002). The Brand Mindset. Yogyakarta: Penerbit Andi.

Kurnianto, R. (2017). Seni Reyog Ponorogo, Sejarah, Nilai dan Dinamika dari Waktu ke Waktu.Yogyakarta: Buku Litera.

Ponorogo, B. P. S. K. (2020). Kabupaten Ponorogo Dalam Angka 2020. Ponorogo: BPS Kabupaten Ponorogo.

Ponorogo, P. K. D. II. (1994). Mengenal Potensi dan Dinamika Ponorogo. Ponorogo: Pemerintah Kabupaten Daerah Tingkat II Ponorogo.

Ponorogo. B. K. (2016). RPJMD Kabupaten Ponorogo Tahun 2016-2021. Ponorogo: Bidang Perekonomian Bappeda Kabupaten Ponorogo.

Ponorogo. P. K. (2013). Pedoman Dasar Kesenian Reyog Ponorogo, Dalam Pentas Budaya Bangsa, Edisi. 2. Ponorogo: Dinas Kebudayaan dan Pariwisata Kabupaten Ponorogo.

Rose, G. (2001). Visual Methodologies, London: Sage Publication Ltd.

Sihombing, I. J. (2010). Mengemas Bahasa Iklan. Suara Merdeka, 3 April 2010, 1.

Simatupang, G.R.L.L. (2019). Play and Display: Dua Moda Pergelaran Reyog Ponorogo Jawa Timur. Yogyakarta: Program Studi Pengkajian Seni Pertunjukan dan Seni Rupa, Sekolah Pascasarjana Lintas Disiplin, Universitas Gajah Mada.

Soemarto. (2014). Menelusuri Perjalanan Reyog Ponorogo. Ponorogo: CV. Kotareog Media.

Tabrani, P. (2009). Bahasa Rupa, Bandung: Penerbit Kelir, 8.

Turok, I. (2009). The Distinctive City: Pitfalls in the Pursuit of Differential Advantage. Environment and Planning A: Economy and Space, 41(1), 13-30. https://doi.org/10.1068/a37379.

Yurisma, D. Y., Waspodo, A. E. B., \& Sachari, A. (2018), Kesenian Tradisi Reog Sebagai Pembentuk Citra Ponorogo. Jurnal Visualita, 7(1), p. 1-15.

Agus Budi Setyawan is a Lecturer at Mercu Buana University, Jakarta. He lectures at the Faculty of Design and Creative Arts in the field of visual communication design. Graduated with a Bachelor in Visual Communication Design from the Indonesian Computer University, Bandung, in 2007. Following this, he received a Master's degree in Visual Communication Design from the Indonesian Art Institute, Yogyakarta, in 2012. He is currently a candidate for a Doctoral in Visual Communication Design at Indonesian Art Institute, Surakarta. His research interest in regional and city branding base on local identity. He has published the results of his research in several journals, delivered seminars and international conferences. Besides, in 2014 he was involved as a declarator for the formation of the Indonesian Visual Communication Designers Association, and in 2016 
became an expert consultant in the preparation of the Maritime and Cultural Tourism Guidelines for the Ministry of Tourism of the Republic of Indonesia.

Nanik Sri Prihatini is a Professor of Dance Research Methodology at the Indonesian Institute of the Arts, Surakarta. Obtained a Bachelor's degree in Karawitan Dance from the Indonesian Karawitan Academy-Surakarta in 1984. In 2000 obtained a Master's degree and a Doctor of Cultural Studies from Udayana University, Bali 2006. From 1978 until now, she has been a lecturer at the Department of Dance, Faculty of Performing Arts, The Indonesian Institute of the Arts Surakarta. Since 2000 as a lecture at the Hindu Dharma College-Klaten, in 2005 as a lecture at the Postgraduate Program in Religion and Culture, Hindu University of Indonesia, Denpasar. In 2006 lecturing at the Postgraduate Program at the Indonesian Institute of the Arts Surakarta. Her main research interest is dance. Her research experiences include the Srimpi Tamenggito Dance in Surakarta, the Srimpi Glondongpring Dance at the Surakarta Palace, the Srimpi Manggala Retna Dance by S. Ngaliman, Kedu Regional Folk Art, Central Java Province. Some of the books that have been published include Seni pertunjukan rakyat Kedu, Dolalak Purworejo, and Kajian tari Nusantara.

Sri Rochana Widyastutieningrum is a Professor of Dance at the Indonesian Institute of the Arts, Surakarta. Obtained a Bachelor's degree in Karawitan Dance from the Indonesian Karawitan Academy-Surakarta in 1984. In 1994 obtained a Master's Degree and obtained a Doctorate Degree in Performing Arts from Gajah Mada University, Yogyakarta, in 2006. Since 1984 she has been a lecturer at the Indonesian Institute of the Arts (ISI) Surakarta while lecturing and guiding students in the Undergraduate, Masters, and Doctoral Programs. She has often tested various universities and is active in various arts cultural activities. Several dance works have been created, including Srimpi Menak Lare Dance, Rama Sinta Dance, and Gambyong Sekar Arum Dance (2018). Her main interest is in dance; her scientific works have been published in various journals, both national and international. Often becomes a presenter in various seminars, both national and international. Apart from being a presenter, she is often a resource person in various art development activities, especially traditional dance. Some of the books that have been published include Sejarah Tari Gambyong: Seni Rakyat Menuju Istana (2004, first published), Langendriyan Mangkunegaran: Pembentukan dan Perkembangan Bentuk Penyajiannya (2004), Tayub di Blora Jawa Tengah: Pertunjukan Ritual Kerakyatan (2007), Penulisan Kritik Tari, co- authored with RM Pramutomo, Pengantar Koreografi (2011), co-authored by Dwi Wahyudiarto, Sejarah Tari Gambyong: Seni Rakyat Menuju Istana (2004, second published), Revitalisasi Tari Gaya Surakarta (2012), and Suyati Tarwo Sumosutargio: Maestro Tari Gaya Mangkunegaran (2018).

Didit Widiatmoko Soewardikoen is a Senior Lecturer in the Master Design Department of Telkom University. Explore the field of graphic design, especially advertising and visual branding. Obtained a Master of Design and a Doctor of Art \& Design from Institut Teknologi Bandung. Before switching professions as a lecturer, he had 20 years of experience in marketing communication in the aircraft industry. Books written include Visual Communication Design Research Methodology, 1950's Indonesian Advertising Visualization, Indonesian Graphic Design Anthology. Conferences speeches and scientific writings at international seminars, accredited national journals, as well as reviewers of several accredited national journals. 